\section{Олена СВЯТУН}

\section{Відповідність законодавства України положенням права СС про тимчасово відряджених працівників}

\begin{abstract}
У статті досліджуються особливості правового регулювання статусу тимчасово відряджених працівників в Європейському Союзі та Україні. Подано характеристику чинних нормативно-правових актів Євросоюзу стосовно відряджених працівників, а також стану відповідності чинного українського законодавства в цій сфері. Доведено, що в наш час існує невідкладна потреба у створенні в нашій державі відповідної правової бази 3 метою захисту прав та соціальних гарантій українських працівників, відряджених до держав-членів ЄС.
\end{abstract}

Ключові слова: Європейський союз, Україна, відряджені працівники, свобода надання послуг, мінімальні ставки оплати праці.

The article examines the features of legal regulation of the status of temporarily posted workers in the European Union and Ukraine. The characteristic of the current regulatory legal acts of the European Union is given in relation to the posted workers, as well as the state of compliance of the current Ukrainian legislation in this area. It has been proved that in our time there is an urgent need to create in our country an appropriate legal framework in order to protect the rights and social guarantees of Ukrainian workers posted in the EU Member States.

Keywords: European Union, Ukraine, posted workers, freedom of service, minimum payments rates.

На внутрішньому ринку Свропейського Союзу, де юридичні особи можуть вільно надавати послуги в інших державах-членах, зрозуміло, що підприємства віддають перевагу наданню транскордонних послуг шляхом залучення своїх власних працівників, а не звертаючись до місцевих субпідрядників та місцевої робочої сили. Особливо ця проблема стоїть гостро, коли «відрядження» власних працівників дозволяє таким підприємствам надавати послуги з меншими витратами, ніж місцеві підприємства. Якщо такі «відряджені» працівники становлять собою дешевшу робочу силу, ніж місцеві робітники, не менш виразно, що місцеві підприємства сприймають таке працевлаштування як інструмент недобросовісної конкуренції або навіть як «соціальний демпінг».

Регулювання в ЄС зростаючого використання відряджених працівників - явища, що опиняється на перетині внутрішнього ринку та правил охорони праці, виявилося політично чутливим. 3 одного боку, це пов' язане з внутрішніми проблемами самого Союзу. Зокрема, у Великобританії проблема зарубіжної робочої сили з низькою заробітною платою в якості «крадіжки місцевих робочих місць» інтенсивно експлуатувалась як прибічниками виходу з СС, так і тими, хто виступав за залишення Великобританії в складі ЄС під час голосування за Brexit у червні 2016 року. Міграція та вільне пересування фізичних осіб становили центральну тему в кампанії за вихід з СС, яка виступала за закриття кордонів для вільного пересування як рішення міграційного питання.

3 іншого боку, проблема необхідності врегулювання статусу відряджених працівників нещодавно постала і для України. Це пов'язано із різними чинниками. В першу чергу з тим, що українські громадяни погоджуються працювати за заробітну плату на порядок нижчу, ніж ті самі громадяни Польщі, не кажучи вже про німців або французів. Все це спричинило практику деяких компаній 3 держав-членів СС, зокрема з Польщі та Болгарії, щодо залучення працівників з України для наступ- 
ного їх «відрядження» до західноєвропейських держав-членів. Тобто, така компанія, наприклад, 3 Польщі наймає українського працівника, а потім направляє його для роботи, наприклад, до ФРН. Таким чином, прибуток отримують всі залучені сторони, лише працівник з України часто залишається без більшості трудових та соціальних гарантій. Таким чином, проблема відповідності та необхідності наближення українського законодавства до стандартів СС в сфері забезпечення прав тимчасово відряджених працівників на сьогодні стає все більш актуальною для правового регулювання та наукових досліджень.

Перед тим, як перейти до встановлення відповідності законодавства України положенням права Свросоюзу, доцільно з'ясувати, хто ж розуміється під поняттям «відряджений працівник». Так, Директива Ради 96/71/СС від 16 грудня 1996 року про тимчасове відрядження працівників, що здійснюється в рамках надання послуг [1] у статті 1 закріплює, що це працівники, які на законних підставах працевлаштовані на підприємстві, яке засноване в одній державі-члені ЄС, та відряджається до іншої (приймаючої) держави-члена з метою виконання в цій приймаючій державі певної трудової діяльності. Як правило, така трудова діяльність реалізується відповідно до контракту, укладеного між підприємством, що відряджає, та стороною, для якої ці послуги призначені. Також може мати місце «відрядження в межах однієї групи», коли підприємство надсилає працівника для роботи в своє дочірнє підприємство в іншій державі-члені. Третя категорія відряджених працівників охоплює працівників, найманих тимчасовими агентствами 3 працевлаштування, створеними в країні походження, для користувача, який перебуває у приймаючій державі-члені.

Тимчасове відрядження працівників - це явище в СС, що має тенденцію до зростання. 32011 року загальна кількість відряджених працівників збільшилася на 58 \%. Відряджені працівники переважно зосереджені у конкретних галузях, таких як будівництво та виробництво, і дещо менше у сфері освіти, охорони здоров'я, соціальних служб та підприємницькій діяльності. Тим не менш, лише обмежену кількість держав-членів зачіпає наявність відряджених працівників. У 2016 році у 85\% від загальної кількості відряджень державами призначення відряджених працівників були старі держави-члени. Серед країн, яких найбільше це стосується можна виділити Німеччину, Францію та Бельгію, які очолюють перелік країн призначення (і загалом отримали 50 відсотків від загальної кількості відряджень в Свропі). 3 іншого боку, Польща, Німеччина та Словенія є країнами походження відряджених працівників. За статистикою у 2016 р. ФРН, Франція та Бельгія прийняли - 440 тис., 203 тис. та 178 тис. відряджених працівників відповідно - набагато більше працівників, ніж вони відрядили (208 тис., 71 тис. та 108 тис. відповідно). У деяких секторах держави-члени стикаються з все більшою кількістю працівників, відряджених з східно- та центральноєвропейських держав-членів, де рівень заробітної плати загалом є нижчим. Більшість відряджень 3 держав-членів, де заробітна плата є нижчою, відбувається в галузі промисловості, де сфера будівництва становить 45 \%. В цій галузі такі держави-члени, як Бельгія та Австрія прийняла особливо велику кількість відряджених працівників.

Втім слід зазначити, що дивлячись на загальний ринок праці, відрядження працівників залишається відносно обмеженим явищем. Лише 0,6 \% робочої сили ЄС можна вважати відрядженими, що складає близько 2 мільйонів осіб. Не більше третини цих відряджень стосується відряджень 3 держав-членів із низькими заробітними платами до держав-членів з високою заробітною платою. Дійсно також існує велика кількість відряджень між державами-членами з високою заробітною платою, зокрема в сфері послуг. Середня тривалість періоду відряджень становить менше чотирьох місяців.

Відряджені працівники залишаються працевлаштованими роботодавцем у державі-члені, де вони перебувають, і відправляються за кордон лише тимчасово. Тому їх статус охоплюється свободою надання послуг, а не свободою пересування працівників. Оскільки відряджені працівники направляються за кордон лише тимчасово, вони не мають наміру інтегруватися до ринку праці приймаючої держави-члена i, таким чином, залишаються охопленими системою соціального забезпечення держави-члена свого походження. Таким працівникам буде видано портативний документ А1 у їхній державі-члені, який підтверджує, що внески до системи соціального страхування сплачуються за них у цій державі-члені.

Відповідно до Регламенту (СС) № 883/2004 про координацію систем соціального забезпечення [2], до відрядженого працівника продовжує застосовуватися законодавство про соціальне забезпечення держави-члена походження, якщо тривалість роботи в приймаючій державі-члені не перевищує 24 місяців. Це має запобігати надмірному адміністративному навантаженню на підприємства та національні органи влади, оскільки в іншому випадку доведеться змінювати чинну систему соціального страхування для кожного працівника, який надає послуги в іншій державі-члені протягом обмеженого часу.

Проблема правового статусу відряджених працівників та захисту їх прав виникла в СС ще із вступом в 1986 р. Іспанії та Португалії, коли набули поширення побоювання, що «старі» держави-члени 
потерпатимуть від хвилі значних груп працівників 3 цих держав-членів, оскільки Суд ЄС підтвердив право компаній користуватися правом на свободу надання послуг шляхом тимчасового залучення своєї робочої сили. Практика Суду СС щодо забезпечення балансу між свободою руху та захистом працівників спричинила прийняття Директиви Ради 96/71/СС від 16 грудня 1996 року про тимчасове відрядження працівників, що здійснюється в рамках надання послуг (далі - Директива 96/71/ЄC), а згодом в 2014 р. Директиви Свропейського Парламенту та Ради 2014/67/СС від 15 травня 2014 року про застосування Директиви Ради 96/71/ СС про відрядження працівників, що здійснюється в рамках надання послуг та внесення змін до Регламенту (СС) 1024/2012 про адміністративне співпрацю через інформаційну систему внутрішнього ринку («Регламент про IMI») (далі - Директива 2014/67/СС) [3].

Директива 96/71/СС запровадила обов'язкові правила для всіх відряджених працівників, залишаючи визначення поняття працівника у відповідності до положень законодавства приймаючої держави-члена. "Ядро" положень Директиви стосується тих питань, які безпосередньо стосуються працівника та підприємства, що здійснює відрядження, під час виконання відрядження, таких як мінімальні ставки заробітної плати, включаючи оплату понаднормових, оплачувані щорічні відпустки, максимальні періоди роботи, а також питання безпеки, охорони праці та гігієни на виробництві. Ці умови повинні бути гарантовані підприємством, що відряджає, на основі законодавчої бази, що застосовується у приймаючій державі-члені. 3 цього переліку виключаються положення про звільнення та стандарти, що стосуються представництва працівників, оскільки вони не є актуальними для короткострокової тривалості роботи, що надається в державі-члені.

Оскільки ядро захисних прав застосовується у відповідності з правилами приймаючої держави-члена, то справді не було б сенсу регулювати ситуації, щодо яких законодавством цієї держави-члена захист не передбачений. Директива 96/71/ЄС не встановлює жодного максимального періоду для діяльності по відрядженням, що підпадає під ії дію. Аналогічно, вона не визначає жодної мінімальної тривалості, хоча містить виключення для працівників, які відряджаються на строк коротший, ніж вісім днів для зборки або монтажу товарів, а також дозволяє державам-членам виключати таку діяльність, відрядження за якою не перевищує одного місяця або яка стосується «несуттєвої роботи». Однак Суд Європейського Союзу вказав, що можуть бути обставини, що передбачають декілька та короткотерміновий перетин кордонів, коли приймаюча держава-член може непропорційно застосовувати своє законодавство щодо мінімальної заробітної плати.

Проблема, яка викликала найбільшу дискусію в процесі прийняття Директиви 96/71/ЄС та продовжувала існувати після іï транспонування, - це застосування вимоги виплачувати працівникам мінімальні ставки оплати праці. Директива 96/71/ЄС визначає, що законодавство та практика приймаючої держави-члена визначає поняття мінімальних ставок оплати праці (п. 3 ст. 3), що вказує на те, що нарахування, специфічні для відряджень, повинні вважатися частиною мінімальної заробітної плати, якщо вони не сплачуються за рахунок відшкодування фактично понесених робітниками витрат, таких як витрати на проїзд, харчування та житло (п. 7 ст. 3). Оскільки Директива 96/71/ЄС не вказує, що саме підпадає під поняття мінімальних ставок оплати праці, національні суди повинні були визначати це поняття в кожному конкретному випадку. На прохання роз'яснити це поняття, Суд Європейського Союзу вирішив, що законодавство приймаючої держави-члена визначає складові елементи мінімальних ставок оплати праці, при цьому вказуючи, що національне законодавство або колективні договори не повинні мати наслідком перешкоджання свободі надавати послуги. Поняття мінімальної заробітної плати не включає нарахування чи доплати, які законодавство або практика приймаючої держави-члена не визначає як складові елементи мінімальної заробітної плати і які змінюють взаємозв'язок між послугою, що надається працівником, та компенсацією отриманою за неї.

Подальше роз'яснення поняття мінімальної заробітної плати було результатом рішення у справі Sähköalojen ammattiliitto (C-396/13, 2015) [10] щодо профспілки в електроенергетиці, яка подала позов про нарахування, належні працівникам, відрядженим у Фінляндію, польським підприємством. Польські роботодавці не врахували кілька нарахувань, включених до колективного договору. Суд кваліфікував добові, встановлені угодою, як допоміжні доплати, характерні для відрядження за змістом п. 7 ст. 3 Директиви, оскільки вони мали за мету усунути недоліки, пов'язані з тим, що працівник переміщається зі свого звичного робочого середовища. Таким чином, ці доплати повинні вважатися частиною мінімальної заробітної плати і повинні виплачуватися відрядженим працівникам без дискримінації. Те саме стосується компенсації за час подорожі, що застосовується, коли працівник повинен був подорожувати щодня протягом більше однієї години від свого помешкання до місця роботи, за умови, що відряджені працівники були в такій ситуації. Однак інші елементи, такі як покриття витрат на проживання та харчування не вважалися складовими заробітної плати, оскільки вони виплачувались для компенсації витрат на проживання, фактично понесених працівниками під час відрядження. 
Різниця в заробітній платі, яка спричинила поширення відряджень працівників, з плином часу, також призвела до посилення спроб шахрайства або обходу правил, що здійснюються підприємствами, які прагнуть використовувати можливості залучення низькооплачуваної робочої сили. Спроби обійти правила щодо відрядження працівників відбуваються через недотримання законодавства про працю чи нормативно-правових актів, що залишалися непоміченими через обмежені або розпливчасті вимоги співпраці та обміну інформацією для національних органів влади, аж до створення "компаній-поштових скриньок" в державі-члені з низьким рівнем заробітної плати для того, щоб працівники, які відряджалися з цієї держави-члена, виконували роботу в державі-члені 3 високою заробітною платою. Для посилення застосування Директиви 96/71/ЄС в травні 2014 року Європейським парламентом та Радою була прийнята Директива 2014/67/СС.

3 метою запобігання зловживанням та обходу правил стосовно відряджень, Директива 2014/67/ $€ С$ вимагає від національних органів встановлювати, чи є працівники, відряджені на їхню територію, справді відрядженими, чи є справжніми трудові відносини з підприємством у державі-членів, що здійснює відрядження. Таке підприємство повинно здійснювати реальну переважну діяльність у цій державі походження. Приймаюча держава-член повинна безкоштовно оприлюднювати інформацію про умови та підстави, які встановлюються для відряджених на роботу працівників. Така інформація повинна бути чіткою, прозорою, всебічною та легко доступною; у тому числі на офіційному національному веб-сайті. Директива 2014/67/ЄС додатково встановлює обов'язки щодо взаємодопомоги, співпраці та моніторингу та щодо транскордонного виконання адміністративних стягнень та штрафів. Важливо, що Директива 2014/67/ЄС також запровадила правила щодо надання субпідрядів. Держави-члени ЄС повинні були до 18 червня 2016 року впровадити Директиву 2014/67/ ЄС у своє національне законодавство. Деякі країни (наприклад, Бельгія, Іспанія, Італія та Польща) вирішили застосувати положення не лише щодо відрядження працівників між державами-членами, але і для працівників, які приїжджають з країн, які не є членами СС.

Директива 2014/67/ЄС заклала підгрунтя для поліпшення інформування провайдерів послуг та кращого виконання норм щодо захисту працівників, викладених у Директиві 96/71/ЄС, але не призвела до змін цих норм. Оскільки Директива 96/71/ЄС вимагала, щоб відрядженим працівникам гарантувались лише мінімальні ставки оплати праці в приймаючій державі-члені, працівники, які відряджаються, не обов'язково користуються аналогічним захистом стосовно заробітної плати, як місцеві працівники. Як було зазначено вище, різниці у рівнях заробітної плати стали більш помітними після вступу до ЄС країн Східної Європи. Зважаючи на це, Комісія Юнкера у березні 2016 року прийняла рішення здійснити "цільовий" перегляд Директиви 96/71/ЄС. Після тривалої підготовчої роботи Директива (СС) 2018/957 Парламенту та Ради про внесення змін до Директиви Ради 96/71/ЄС від 16 грудня 1996 року про тимчасове відрядження працівників, що здійснюється в рамках надання послуг була прийнята 28 червня 2018 року (далі - Директива 2018/957) [4]. Відповідно до ст. 3 самої Директиви 2018/957 ії положення застосовуватимуться 330 червня 2020 р., а до цього моменту держави-члени повинні прийняти відповідні законодавчі акти на ії виконання.

Головне доповнення запроваджене Директивою 2018/957 стосується зміни поняття «мінімальні ставки оплати праці», що застосовуються до відряджених працівників відповідно абз. с) п. 1 ст. 3. Директиви 96/71/ЄС, на поняття «винагорода», що визначається як «всі складові елементи винагороди, які є обов'язковими відповідно до положень національного законодавства або адміністративних положень, або колективних угод чи арбітражних рішень, які в цій Державі-члені, визнані загальноприйнятними». Згідно $з$ переглянутим абз. с) п. 1 ст. 3, ядро прав, гарантованих відрядженим працівникам, включає всі елементи оплати праці, визначені в приймаючій державі-члені, а не лише мінімальні ставки заробітної плати. Оскільки це положення виключає конкуренцію щодо заробітної платні між відрядженими та місцевими працівниками, це повинно сприяти збільшенню заробітної плати для працівників, що перебувають у державах-членах з високою заробітною платою. Директива 2018/957 також забезпечує "рівні умови" для всіх зацікавлених підприємств.

Нарахування, специфічні для відрядження, згідно з Директивою 2018/957 слід вважати частиною винагороди працівника, якщо вони покривають витрати, фактично пов'язані із відрядженням, такі як проїзд, харчування та проживання. Роботодавець повинен відшкодувати такі витрати відповідно до національного законодавства та / або практики, що застосовується до трудових відносин. Якщо в умовах, що застосовуються до трудових відносин, не визначено, які елементи нарахування відносяться до витрат, а які є частиною винагороди, всі нарахування вважатимуться покриттям витрат, фактично понесених за рахунок відрядження.

Відряджені працівники мають право на доплати або відшкодування витрат на проїзд, харчування та проживання, призначені для працівників, які перебувають не за місцем свого проживання 3 професійних причин, на умовах однакових із місцевими працівниками. Це стосується подорожі до 
місця перебування та 3 місця його перебування у державі-члені призначення або коли вони тимчасово відряджаються з цього робочого місця на інше робоче місце. Крім того, умови проживання відряджених працівників, якщо це передбачено роботодавцем, повинні відповідати правилам, що діють у приймаючій державі.

Колективні договори, які проголошені загальноприйнятними, поширюються на працівників, відряджених у всіх галузях. В даний час це стосується лише будівельної галузі, хоча в деяких державах-членах це вже застосовується для всіх галузей. Крім того, держави-члени також можуть вирішити застосувати:

- колективні угоди або арбітражні рішення, які, як правило, застосовуються до всіх подібних організацій в географічній області та відповідної професії чи галузі;

- колективні договори, які були укладені найбільш типовими роботодавцями та організаціями праці на національному рівні і які застосовуються на всій національній території.

У Директиві 96/71/СС визначено, що відрядження працівників має тимчасовий характер, проте там не міститься роз'яснення поняття "тимчасове". У Регламенті (СС) № 883/2004 про координацію систем соціального забезпечення працівники, що перебувають у державі-члені довше, ніж 24 місяців, вважаються такими, що більше не мають необхідного зв'язку з цією державою-членом, щоб підлягати дії законодавства цієї держави-члена щодо включення в систему соціального забезпечення. Беручи до уваги це положення, Директива 2018/957 встановила, що тимчасово відрядженими працівниками є ті, які перебувають в державі-призначенні протягом терміну у 12 місяці, 3 можливістю подовження цього строку ще на 6 місяців.

Якщо компанія замінює працевлаштованого працівника іншим відрядженим працівником, який виконує те саме завдання на тому самому місці, тривалість відрядження буде сукупною тривалістю періодів відряджень відповідних окремих працевлаштованих працівників. Щоб визначити, чи виконує відряджений працівник «те саме завдання на тому самому місці», що і працівник, якого він замінюють, слід враховувати характер наданої послуги, роботу, яку потрібно виконати, та адресу (адреси) робочого місця, а також інші фактори.

Держави-члени повинні забезпечити, щоб принцип рівного ставлення, передбачений Директивою про тимчасові агентства з питань працевлаштування, застосовувався також і до працівників тимчасових служб.

Компанії-користувачі також повинні повідомити тимчасові агентства, якщо вони мають намір здійснювати транснаціональні послуги з тимчасовим працівником агентства в іншій державі-члені, крім тієї, де працівник зазвичай працює у тимчасовому агентстві.

Переглянута Директива щодо відряджених робітників застосовуватиметься до транспортного сектору лише після того, як набуде чинності галузеве європейське законодавство, про яке зараз ведуться переговори. До цього часу виключення дії положень Директиви 96/71/СС для працівників сфери міжнародних перевезень продовжуватимуть діяти.

Розглянувши в загальних рисах правовий механізм захисту прав відряджених працівників в Свропейському Союзі, можна перейти до визначення відповідності українського законодавства стандартам в зазначеній сфері.

Тут можна виділити дві ситуації: перша - іноземні громадяни відряджаються на територію України. Друга - українські громадяни відряджаються за кордон.

3 огляду першої ситуації, слід звернути увагу на положення ст. 26. Конституції України, відповідно до якої іноземці та особи без громадянства, що перебувають в Україні на законних підставах, користуються тими самими правами і свободами, а також несуть такі самі обов'язки, як і громадяни України, - за винятками, встановленими Конституцією, законами чи міжнародними договорами України. А згідно з ст. 33 - кожному, хто на законних підставах перебуває на території України, гарантується свобода пересування, вільний вибір місця проживання, право вільно залишати територію України, за винятком обмежень, які встановлюються законом [5]. Ці положення відтворені у Закон України «Про правовий статус іноземців та осіб без громадянства» 2012 р. у ст. 3 «Засади правового статусу іноземців та осіб без громадянства [6].

Закон України «Про зайнятість населення» 2013 р. (в редакції 2019 р.) у ст. 1 п. 41) визначає термін «відряджені іноземні працівники» [7]. Отже, згідно з чинним законодавством ними є іноземці та особи без громадянства, направлені іноземним роботодавцем в Україну для виконання певного обсягу робіт (послуг) на підставі договорів (контрактів), укладених між українським та іноземним суб'єктами господарювання. Цей статус є підставою для роботодавця отримати для іноземця або особи без громадянства дозволу на працевлаштування (ст. $42^{1}$ ). Ст. $42^{2}$ передбачає перелік документів для отримання дозволу на застосування праці іноземців та осіб без громадянства та продовження його дії. Зокрема, для працевлаштування відряджених іноземних працівників додатково подається 
копія договору (контракту), укладеного між українським та іноземним суб'єктами господарювання, яким передбачено застосування праці іноземців та осіб без громадянства, які направлені іноземним роботодавцем в Україну для виконання певного обсягу робіт (надання послуг), а для внутрішньокорпоративних цесіонаріїв - рішення іноземного суб'єкта господарювання про переведення іноземця або особи без громадянства на роботу в Україну та копія контракту, укладеного між іноземцем або особою без громадянства та іноземним суб'єктом господарювання, про переведення на роботу в Україну з визначенням строку роботи в Україні.

Таким чином, можна зробити висновок, що в нашому законодавстві передбачені лише можливості набуття статусу відрядженого працівника для іноземних громадян.

Що стосується, ситуації відрядження українців за кордон, то вбачається, що в нашій правовій системі відсутнє специфічне законодавство цій в галузі. Правове регулювання цих питань відбувається на підставі загальних положень щодо працевлаштування працівників-мігрантів, а також двосторонніх угод України з питань працевлаштування.

Закон України «Про міжнародне приватне право» 2005 р. (в редакції 2018 р.) [8] у ст. 52. визначає право, що застосовується до трудових відносин, а саме: до трудових відносин застосовується право держави, у якій виконується робота, якщо інше не передбачено законом або міжнародним договором України. Наразі такі договори укладені з низкою держав, зокрема 3 Лівією, Польщею, Іспанією, Португалією, Азербайджаном, Білоруссю, Латвією, Литвою, найновіша було підписана в 2016 з Державою Ізраїль. У ст. 53 встановлюється, що трудові відносини громадян України, які працюють за кордоном, регулюються правом України в разі, якщо: 1) громадяни України працюють у закордонних дипломатичних установах України; 2) громадяни України уклали 3 роботодавцями - фізичними або юридичними особами України трудові договори про виконання роботи за кордоном, у тому числі в їх відокремлених підрозділах, якщо це не суперечить законодавству держави, на території якої виконується робота; 3) це передбачено законом або міжнародним договором України.

В нашій державі діють два закони, що певною мірою стосуються працевлаштування українських громадян за кордоном. По-перше, це Закон України «Про зовнішню трудову міграцію» 2015 р. [9], який поширює свою дію на трудових мігрантів, які: 1) працюють на підставі трудового договору (контракту); 2) самостійно забезпечують себе роботою; 3) надають оплачувані послуги (виконують роботи); 4) здійснюють іншу оплачувану діяльність, не заборонену законодавством держави перебування. (ст. 1). Ст. 8 Закону передбачає, що права трудових мігрантів, зокрема на належні умови праці, винагороду, відпочинок і соціальний захист, регулюються законодавством держави перебування та міжнародними договорами України, згода на обов' язковість яких надана Верховною Радою України.

Цим законом також передбачено, що працевлаштування трудового мігранта в державі перебування може здійснюватися: органами виконавчої влади відповідно до укладених міжнародних договорів, згода на обов'язковість яких надана Верховною Радою України; або суб'єктом господарювання, що надає послуги з посередництва у працевлаштуванні за кордоном на підставі ліцензіі, виданої відповідно до закону; або трудовим мігрантом самостійно. При цьому у разі працевлаштування органами виконавчої влади відповідно до укладених міжнародних договорів, згода на обов'язковість яких надана Верховною Радою України, або суб'єктом господарювання, що надає послуги 3 посередництва у працевлаштуванні за кордоном на підставі ліцензії, виданої відповідно до закону, трудовому мігранту перед від'їздом до держави перебування стороною, що сприяє працевлаштуванню, видається проект трудового договору (контракту), завірений іноземним роботодавцем. Проект трудового договору (контракту) викладається українською мовою та однією чи більше мовами, що використовуються в державі перебування, і містить зобов'язання, які бере на себе іноземний роботодавець, зокрема щодо: 1) умов праці (у тому числі щодо забезпечення безпечних та нешкідливих умов праці), оплати праці (у тому числі щодо розміру гарантованої заробітної плати), відрахувань із заробітної плати; 2) тривалості робочого часу і часу відпочинку, строку дії трудового договору (контракту) та умов його розірвання; 3) надання соціальної та медичної допомоги, здійснення соціального страхування; 4) відшкодування шкоди, заподіяної здоров'ю внаслідок нещасного випадку на виробництві або тимчасової непрацездатності; 5) репатріації трудового мігранта.

Діяльність суб'єктів господарювання, які надають послуги з посередництва у працевлаштуванні за кордоном регулюється Законом України «Про зайнятість населення» 2013 р. у ст. 38 [7]. Така діяльність підлягає ліцензуванню і регулюється законами України "Про ліцензування певних видів господарської діяльності", "Про зовнішньоекономічну діяльність", самим Законом «Про зайнятість населення» та іншими законодавчими актами України. Послуги з посередництва у працевлаштуванні на роботу за кордоном надаються відповідно до заявок іноземного роботодавця (його контрагента) щодо вільних робочих місць (вакансій) і лише в межах укладених іноземними суб'єк- 
тами господарювання зовнішньоекономічних договорів (контрактів) про надання посередницьких послуг у сфері працевлаштування з метою сприяння підписанню трудового договору (контракту найму). Обов'язковим додатком до зовнішньоекономічного договору (контракту) про надання посередницьких послуг у сфері працевлаштування за кордоном є проект трудового договору, завірений іноземним роботодавцем. Суб'єкт господарювання, який надає послуги 3 посередництва у працевлаштуванні за кордоном, несе відповідальність згідно із законодавством за погіршення умов трудового договору, укладеного між особою та іноземним роботодавцем, копія якого зберігається у такого суб'єкта протягом трьох років. Надання послуг з посередництва у працевлаштуванні за кордоном здійснюється після укладення договору про надання послуг з посередництва у працевлаштуванні за кордоном між особою та суб'єктом господарювання. Суб'єкт господарювання, який надає послуги 3 посередництва у працевлаштуванні за кордоном, не має права отримувати від осіб, яким надані такі послуги, плату до підписання акта виконаних робіт. Суб'єкт господарювання, який надає послуги 3 посередництва у працевлаштуванні за кордоном, сприяє громадянам, яким надано такі послуги, у вирішенні питань правового і соціального захисту та інформує їх про механізм добровільної участі у загальнообов'язковому державному соціальному страхуванні. Громадяни у період трудової діяльності за кордоном мають право брати участь у загальнообов'язковому державному соціальному страхуванні, зокрема пенсійному, відповідно до законодавства України, що дає їм право на соціальний захист у разі настання відповідних страхових випадків.

Таким чином, можна зробити висновок, що чинне українське трудове законодавство потребує суттєвого оновлення задля того, щоб в на законодавчому рівні були запроваджені стандарти СС захисту прав відряджених працівників. Не зважаючи на те, що Україна не є державою-членом СС, iї працівники уже достатньо давно та ефективно залучаються до ринку праці ЄС. Проте відсутність юридичних механізмів захисту їх прав призводить до того, що вони опиняються у невигідному становищі, порівняно 3 працівниками, які є громадянами держав-членів. Крім того, беручи до уваги той факт, що Угода про асоціацію між Україною та СС забороняє дискримінацію працівників, які на законних підставах перебувають на території СС та України, це ставить питання про необхідність внесення змін до чинних угод про працевлаштування (які вже украдені з певними державами-членами (С), а також укладення таких угод з тими державами, до яких найбільше спрямовується робоча сила з України, з метою передбачення випадків відрядження працівників та встановлення елементів правового статусу.

1. Directive 96/71/EC of the European Parliament and of the Council of 16 December 1996 concerning the posting of workers in the framework of the provision of services. / / Official Journal. - 1997. - 21.11. L 18. - P. 1- 6.

2. Regulation (EC) No 883/2004 of the European Parliament and of the Council of 29 April 2004 on the coordination of social security systems. / / Official Journal. - 2004. - 30.04. - L 166. - P. 1- 99.

3. Святун О. Директива Європейського Парламенту та Ради 2014/67/ЄС від 15 травня 2014 року про застосування Директиви Ради 96/71/СС про відрядження працівників, що здійснюється в рамках надання послуг, та внесення змін до Регламенту (СС) 1024/2012 про адміністративну співпрацю через інформаційну систему внутрішнього ринку («Регламент про IMI») та Коментар до неї. / О. Святун. // Український часопис міжнародного права. - 2018. - № 2. - С. 69 - 86.

4. Directive (EU) 2018/957 of the European Parliament and of the Council of 28 June 2018 amending Directive 96/71/EC concerning the posting of workers in the framework of the provision of services. // Official Journal. - 2004. - 30.04. - L 166. - P. 1- 99.

5. Конституція України [Електронний ресурс]. - Режим доступу: https://zakon.rada.gov.ua/ laws/show/254\%D0\%BA/96-\%D0\%B2\%D1\%80.

6. Закон України «Про правовий статус іноземців та осіб без громадянства» [Електронний ресурс]. - Режим доступу: https://zakon.rada.gov.ua/laws/show/3773-17.

7. Закон України «Про зайнятість населення» [Електронний ресурс]. - Режим доступу: https:// zakon.rada.gov.ua/laws/show/5067-17.

8. Закон України «Про міжнародне приватне право» [Електронний ресурс]. - Режим доступу: https:/ / zakon.rada.gov.ua/laws/show/2709-15.

9. Закон України «Про зовнішню трудову міграцію» [Електронний ресурс]. - Режим доступу: https://zakon.rada.gov.ua/laws/show/761-19. 
10. Judgment of the Court (First Chamber) of 12 February 2015 Sähköalojen ammattiliitto ry v Elektrobudowa Spolka Akcyjna Request for a preliminary ruling from the Satakunnan käräjäoikeus. Case C-396/13. [Електронний ресурс]. - Режим доступу: http:/ /curia.europa.eu/juris/liste.jsf?num=C-396/13.

11. Nuffel Piet Van. The Posting of Workers Directive Revised: Enhancing the Protection of Workers in the Cross-border Provision of Services. / Nuffel Piet Van, Afanasjeva Sofia. / / European Papers. - 2018. - No 3. - Vol. 3. - Pp. 1401-1427.

12. Maes Sophie. New European rules for posted workers. / Maes Sophie. [Електронний ресурс]. - Режим доступу: https://www.lexology.com/library/detail.aspx?g=95e0a651-c8b3-45d4-9eb06f6cc3b3aaad.

\section{Summary}

Due to the significant enlargement of the EU over the last 15 years the Europeans came across of the issue of posted workers being sent by his/her employer on temporary basis in order to provide services. Currently the major home Member State are situated in the Central and Eastern Europe and major receiving Member States are in the Western Europe. The main problem that has to be solved is the problem of payment of the posted workers as the payment rates in the Central and Eastern Europe are much lower than in other EU Member State.

In 1996 the European Parliament and of the Council adopted the Directive 96/71/EC concerning the posting of workers in the framework of the provision of services. It turned out to be the first attempt to introduce standards of posted workers rights protection common for the whole EU internal market. Unfortunately this attempt was not successful as this Directive provided for the legal status of posted workers but left aside the procedural issues of posting and the enforcement of its provisions.

In 2014, the EU adopted Directive 2014/67/EU of the European Parliament and of the Council on the enforcement of Directive 96/71/EC to strengthen the protection of posted workers and to stop circumventing rules. The aim was to expand and harmonize the practical scope of application, enforcement and execution of the Directive on posted workers. But even this action proved not to be sufficient.

For that reason in 2018, the Council of the EU approved the revision Directive 96/71/EC concerning the posting of workers. The revised directive aims to promote cross-border provision of services, while ensuring fair competition and respect for the rights of workers who are employed in one Member State and temporarily employed by another employer (posted workers). More specifically, the Directive seeks to ensure a fair wage and a level playing field for the posted workers and local companies in the host country while maintaining the principle of free movement of services.

Ukrainian citizens have been the part of the European labour market for a long time although a lot of Ukrainians are employed illegally. While analyzing the compliance of the Ukrainian legislation with the EU legal framework on the posted workers the conclusion was made the Ukrainian legal framework lacks special provisions on posting Ukrainian abroad. The lack of legal mechanisms to protect the rights of the Ukrainian posted workers causes them to be disadvantaged compared to workers who are nationals of Member States. In addition, given the fact that the Association Agreement between Ukraine and the EU prohibits discrimination against workers legally employed in the territory of the EU and Ukraine, this raises the need for amendments to existing employment agreements (which have already been concluded with certain EU Member States), as well as the conclusion of such agreements with those countries to which the workforce from Ukraine is most directed, in order to anticipate cases of posting of workers and to establish elements of their legal status. 